\title{
Descriptions of the two-eyed African spider genera Chedimanops gen. $n$. and Hybosidella gen. $n$. (Araneae, Palpimanidae, Chediminae)
}

\author{
Sergei L. Zonstein', Yuri M. Marusik 2,3,4 \\ I Department of Zoology, Steinhardt Museum of Natural History, Tel-Aviv University, 69978 Tel-Aviv, Israel \\ 2 Institute for Biological Problems of the North RAS, Portovaya Str. 18, Magadan, Russia 3 Zoological Museum, \\ Biodiversity Unit, FI-20014 University of Turku, Finland 4 Department of Zoology \& Entomology, University \\ of the Free State, Bloemfontein 9300, South Africa \\ Corresponding author: Sergei L. Zonstein (znn@post.tau.ac.il) \\ Academic editor: P. Stoev | Received 9 December 2016 | Accepted 22 February 2017 | Published 27 February 2017 \\ http://zoobank.org/E40AD585-3569-43BE-954A-DF8AEA64E958 \\ Citation: Zonstein SL, Marusik YM (2017) Descriptions of the two-eyed African spider genera Chedimanops gen. n. and \\ Hybosidella gen. n. (Araneae, Palpimanidae, Chediminae). African Invertebrates 58(1): 23-47. https://doi.org/10.3897/ \\ AfrInvertebr.58.11448
}

\begin{abstract}
Two new genera of chedimine palpimanids are described. Chedimanops gen. n. includes the type species,

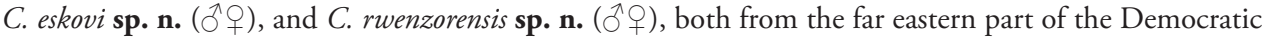
Republic of Congo (Rwenzori Mts.). The monotypic Hybosidella gen. n. is based on H. etinde sp. n. ( $\widehat{(})$ from Cameroon. The new genera differ from all other Palpimanidae by possessing only the anterior median eyes (all other eyes are lost). These new genera can be distinguished from one another by the shape of the thoracic fovea (a narrow bracket-shaped pit vs. a longitudinal groove, respectively), as well as by the structure of the abdominal scuta and the male copulatory organ, peculiarities of coloration, amongst other characters. The taxonomic position and relationships of the newly described taxa are briefly discussed. The distinctive characters and a key to both species of Chedimanops gen. n. are also provided.
\end{abstract}

\section{Keywords}

Aranei, brush-footed spiders, Cameroon, Congo, new genus, new species, taxonomy

Copyright Sergei L. Zonstein, Yuri M. Marusik. This is an open access article distributed under the terms of the Creative Commons Attribution License (CC BY 4.0), which permits unrestricted use, distribution, and reproduction in any medium, provided the original author and source are credited. 


\section{Introduction}

The majority of spiders have eight eyes, although there are several families and many genera with six eyes. Fewer spiders have four eyes or none (Jocqué and DippenaarSchoeman 2006). The two-eyed spiders are known only in four unrelated families belonging to mygalomorphs and haplogynes. Two eyes are present in the monotypic Micromygale Platnick \& Forster, 1982 (Microstigmatidae), in most genera of Caponiidae (Platnick 1993, in several genera of Tetrablemmidae (Lehtinen 1981), and in two genera of the Oonopidae, Coxapopha Platnick, 2000 and Diblemma O.P.-Cambridge, 1908 (Platnick 2000). In two families, Microstigmatidae and Tetrablemmidae, the eyes that seem to be present are anterior laterals (Platnick and Forster 1982; Lehtinen 1981; respectively), while in the Caponiidae with two eyes, only the anterior medians are retained (Jocqué and Dippenaar-Schoeman 2006). Within the "entelegyne" families, two-eyed species have never been previously reported.

While studying material from the Royal Museum for Central Africa (Tervuren, Belgium), the senior author found several specimens of Palpimanidae from Africa that only have two eyes. Almost all the palpimanids known to date have eight eyes, while only $\mathrm{Hy}$ bosida Simon, 1898 is six-eyed (Jocqué and Dippenaar-Schoeman 2006). As in the case of the Caponiidae, the remaining pair was found to be represented by the anterior median eyes. A study of the somatic characters and the copulatory organs of these two-eyed palpimanids has revealed that they belong to three undescribed species that can be placed in two new genera belonging judging from their minute size and structure of the male copulative organs (which is considered and discussed below) to the subfamily Chediminae. This paper describes the new taxa and discusses their newly discovered characters.

\section{Material and methods}

\section{Depositories}

MRAC Royal Museum for Central Africa, Tervuren, Belgium;

NCA National Collection of Arachnida, ARC-Plant Protection Research Institute, Pretoria, South Africa;

NHML Natural History Museum, London, UK;

NRS Naturhistoriska riksmuseet, Stockholm, Sweden;

SMF Senckenberg Museum, Frankfurt am Main, Germany;

TAU Steinhardt Museum of Natural History, Tel-Aviv University, Israel;

ZMUT Zoological Museum, University of Turku, Finland.

\section{Comparative material examined}

Boagrius incisus Tullgren, 1910: TANZANIA: $1 \overbrace{}^{\Uparrow}$ syntype Kibonoto (Kilimanjaro), viii-ix.1905, Y. Sjöstedt (NRS). 
Boagrius pumilus Simon, 1893: MALAYSIA: Pahang Province: 10 Bukit Fraser, 18.xi.1984, P. Lehtinen (ZMUT).

Chedima purpurea Simon, 1873: MOROCCO: $1 \delta^{\Uparrow}$ Taza, 25.ii.2004, D.W. Wrase (SMF); 1 9 Had Msila, 21.ii.2004, D.W. Wrase (SMF).

Diaphorocellus biplagiatus Simon, 1893: SOUTH AFRICA: Western Cape: $1{ }^{\lambda}$ Beaufort-West, Farm Katdoornkuil, 3-6.xii.2007, D.H. Jacobs (NCA 2008/4672); 1 우 Beaufort-West, Farm Kantkraal, 3-6.xii.2007, D.H. Jacobs (NCA 2008/2607).

Hybosida dauban Platnick, 1979: SEYCHELLES: 10 Silhouette Isl., Mon Plaisir, 20.xii.1993, J. Gerlach (ZMUT); 1 ㅇ same island, Gratte Fesse, 12-24.i.1999, J. Gerlach and M. Saaristo (ZMUT).

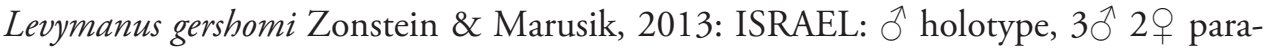
types Qetura, 8.v.2003, E. Topel (TAU).

Palpimanus sogdianus Charitonov, 1946: TAJIKISTAN: $1{ }^{\Uparrow} 1$ ㅇ Beshkent, 17.iv.1989, S. Zonstein (TAU).

Palpimanus transvaalicus Simon, 1893: SOUTH AFRICA: Limpopo: $4{ }^{\lambda} 1$ iq Tuinplaas, 17.ix.2002, M. van Jaarsveld (NCA 2003/379).

Sarascelis junquai Jézéquel, 1964: CÔTE D’IVOIRE: $2 \widehat{O} 1$ ㅇ Titekro, 29.ii.1984, R. Schouten and J. Buysen (MRAC 166073).

Scelidocteus schoutedeni Benoit, 1974: D.R. CONGO: Équateur Province: đ̂̉ holotype Kumungu, iv.1921, H. Schouteden (MRAC 15551).

Scelidomachus socotranus Pocock, 1899: YEMEN: Socotra: đ holotype Dahamis, xii.1898, W.R.O. Grant (NHML); $1 \delta^{\Uparrow}$ paratype Thluteen, xii.1898, W.R.O. Grant (NHML).

Photographs were taken in dishes of different sizes with a paraffin or cotton layer on the bottom. Specimens were photographed using a Canon EOS 7D camera attached to an Olympus SZX16 stereomicroscope and with a SEM JEOL JSM-5200 scanning electron microscope at the Zoological Museum, University of Turku. Digital images were processed using the "CombineZP" image stacking software (http://www. hadleyweb.pwp.blueyonder.co.uk/).

The width of the sternum was measured between the bases of the coxae of legs II. Illustrations of the female copulative organs were made after maceration in $20 \%$ potassium hydroxide aqueous solution and exposure for a few minutes in an alcohol/water solution of Chlorazol Black. Lengths of the leg segments were measured on the dorsal side. All measurements are given in millimetres.

Abbreviations (except encoded in the text):
ALE anterior lateral eyes
ALS anterior lateral spinnerets
AME anterior median eyes
CH carapace height
CL carapace length
CW carapace width
$\mathrm{CyH}$ clypeus height 


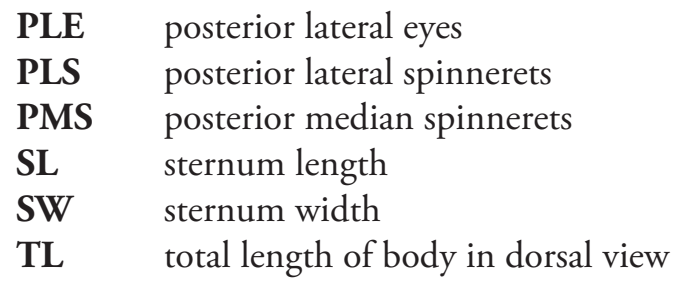

\section{Taxonomy}

\section{Family Palpimanidae Thorell, 1870}

\section{Genus Chedimanops gen. $\mathbf{n}$.}

http://zoobank.org/B316E08A-433B-4846-8078-95EBE87A33E0

\section{Type species. Chedimanops eskovi sp. n.}

Etymology. The generic name is combined from Chedima, the nominative genus of the Chediminae (Palpimanidae), resembling the studied genus habitually, and Nops, the well-known spider genus of the family Caponiidae, in which all members also have only two eyes. The gender is masculine.

Diagnosis. The new genus can be easily distinguished from all known genera of the Palpimanidae, except Hybosidella gen. n., by having only two eyes (all eyes except AME are lost, whereas other Palpimanidae have either 8 or 6 eyes). Chedimanops gen. n. can be distinguished from Hybosidella gen. n. by the shape of the thoracic fovea (a narrow bracket-shaped pit $v s$. a longitudinal groove), as well as by the structure of the abdominal scuta and the shape of male copulatory organ, and by possessing the characteristic mottled dorsal pattern of the abdomen (uniformly pale in Hybosidella gen. n.), etc. (cf. Figs $1-4,6-10,12,32$ and 41-43, 54, respectively). Male palp in Chedimanops gen. $n$. has a undivided claw-shaped process $(C p)$ of the embolic division ( $v s$. a divided process with a different shape in Hybosidella gen. n. - $c f$. Figs 33-35, 49-52, 56-57 and 53, 64-66).

Description. Body length 3.0-3.2 in males and 3.1-4.0 in females.

Carapace: very finely granulated, broad-oval in dorsal view and covered with fine setae - very small and appressed anteriorly and laterally, and with longer and thicker ones near the fovea. Cephalic part noticeably raised behind eye area in both sexes. Thoracic fovea narrow, transverse, converging and sharp-angled anteriorly, opened posteriorly (Figs $3,4,6,12,15)$. Two eyes, only AME present, other eyes lost. AME minute-sized, spaced by $0.4-0.7$ of diameter and located on low tubercle. Clypeus 1.9-2.2 times higher than AME diameter (Figs 11, 13). Chelicerae downward-directed, slightly flattened frontally, twice longer than clypeus; stridulatory ridges absent; cheliceral furrow with several peg teeth (Figs 26-29). Sternum with fine reticulation; labium triangular with very deep median suture $(M s$, Fig. 14), nearly as broad at base as it is long.

Legs: formula 1423. Leg cuticle almost smooth. Femur I considerably swollen in proximal part; patella as long as tibia, metatarsus and tarsus short and dilated. Tibia I 
subapically and metatarsus I with long (equal to width of these segments) and dense prolateral scopula. Leg tarsi straight and ascopulate. Claw tufts weakly developed. Leg tarsi with two narrow and dentate claws (Figs 23-25).

Abdomen: ovoidal, slightly extended anteriorly and obtuse posteriorly, with dorsal pattern of numerous small and dense light spots on darker background (Figs 1, 3, 4, 6-10). Abdominal scuta conforming a very short pedicel tube $(P t)$; posterior part of epigastral scutum in females with with strongly sclerotized margins, widely concave near epigastral furrow, without lateral extensions. In males, posterior lateral parts of epigastric scutum with extensions $(E e)$ longer than wide, posterior part near epigastrum with thin concavity. Ventral (postgastral) scutum $\left(P_{s}\right)$ entire, strip-like in female. Males with 2 pairs of scuta, thin strip-like lateral scuta $\left(P_{s} L\right)$ and small median scuta $\left(P_{s} M\right)$. Spinneret group with weakly sclerotised ring encircling spinnerets. AMS small but well-developed; PMS and PLS reduced to a few sessile spigots in females, absent in males (see Fig. 22).

Male palp: short, femur slightly swollen, shorter or subequal in length to cymbium; patella small, as long as wide, thinner than femur; tibia wide, strongly widened, almost 2 times wider than femur, extended dorsally so that ventral side $2-4$ times shorter than dorsal arch; cymbium 1.5-1.7 times longer than basal width, with basal $1 / 3$ wide, and fingerlike distal 2/3; retrolateral-basal part with sparse scopula (Figs 49, 51, 56, 57, 59, 60). Bulb large, tegulum as long as wide and lacking any processes (Figs 33, 34, 50, 52, $56,58)$. Embolic division (Figs 32, 35) imbedded into large tegular cavity ( $T c$, diameter almost equal to tegulum diameter); embolic division composed by large, heavily sclerotized claw-shaped process $(C P)$, with tip directed to the tip of cymbium, inner part of claw-shaped process with accompanying membrane $(\mathrm{Am})$ fused at the base with large membranous process $(M p)$ slightly chitinized in prolateral part (Em?) possibly serving as embolus. Accompanying membrane with barbed tip $(B l)$ in $C$. eskovi sp. n. Sperm duct (spermophore) not evident.

Female copulatory organs: epigastral scuta concave near epigastral furrow, receptacles oval, clearly visible through integument (Figs 2, 5, 36, 39), and separated from one another shorter than their diamater. Vulva: receptacles large, closely spaced, inner part of receptacle (chamber, $C h$ ) is half of size of entire receptacle; grape-shaped glands $(G g)$ large and numerous (8-12), each gland with at least 2 pores each bearing one cilium. Fine threads $(F t)$ long, in $C$. rwenzorensis sp. n., their tips with very fine glands $(F g)$.

Species included. Chedimanops eskovi sp. n. and C. rwenzorensis sp. n.

Distribution. The genus is currently known only from the far eastern part of the Democratic Republic of Congo (Rwenzori Mts.).

\section{Key to species of Chedimanops gen. $\mathbf{n}$.}

1 Intensely coloured; carapace longer than $1.6 \mathrm{~mm}$, claw-shaped process $(C p)$ bent once (Figs 49, 50, 56, 57); membranous process $(M p)$ faint, cymbium 1.7 longer than wide; receptacles spaced from epigastral fold by approx. one diameter (Figs 2, 36), number of grape-shaped glands more than ten (Figs $67-71)$ 
- $\quad$ Pale coloured; carapace shorter than $1.4 \mathrm{~mm}$; claw-shaped process $(C p)$ bent twice (Figs 51, 52), membranous process $(M p)$ large, distinct, cymbium 1.5 times longer than wide; receptacles spaced from epigastral fold by less than one diameter (Figs 5, 39), number of grape-shaped glands less than 10 (Figs 72-75)

C. rwenzorensis sp. $\mathrm{n}$.

\section{Chedimanops eskovi sp. $\mathrm{n}$.}

http://zoobank.org/20F7F9E9-9951-4E5E-ACC5-941362E10794

Figs $1-3,7-11,15-38,49-50,55-60,67-71,76$

Etymology. The specific epithet is given in honour of our good friend and colleague Kirill Eskov (Paleontological Institute, Moscow), the author of many works devoted to the taxonomy of recent and fossil spiders.

Diagnosis. Differs from C. rwenzorensis sp. n. by a darker, more intense, and contrasted colouration, with presence of a weak ventral reticulate pattern on the abdomen, as well as by the shape of copulatory organs. Claw-shaped process of the embolic division has 1 bend ( 2 in C. rwenzorensis sp. n.), longer cymbium with length width ratio 1.7 (1.5 in the related species), swollen tibia and faint membranous process (distinct and large in sibling species). Females clearly differ by the position of receptacles (approximately one diameter from epigastral fold in C. eskovi sp. n. and by less than one radius in $C$. rwenzorensis sp. n.) and the number of grape-shaped glands (more than ten in C. eskovi sp. n. and fewer than ten in C. rwenzorensis sp. n).

Description. Male MRAC 154713 (holotype).

Habitus: as in Figs 3, 7, 38. Measurements: TL 3.15, CL 1.64, CW 1.11, CH 0.74, $\mathrm{CyH}$ 0.19, SL 0.93, SW 0.79. Eyes: AME 0.08, AME-AME 0.04. Colour in alcohol: carapace and chelicerae medium golden-red with light brownish tint, dorsal scutum darker brownish-red; sternum and labium light red, ventral scutum slightly paler yellowish-red; palps and leg I light yellowish-orange, II-IV pale reddish-yellow; abdomen dorsally medium chestnut with numerous, dense and uniformly spread small pale yellowish-brown spots; ventrally, including spinnerets, pale grayish-yellow. Palp: as shown in Figs 32-35, 49-50, 55-60. Femur swollen, 1.8 times longer than wide. Ventral length of tibia four times shorter than dorsal length; cymbium 1.3 times longer than femur; length width ratio $c a$. 1.7. Tegulum with large cavity almost equal to diameter. Claw-shaped process $(C P)$ with one bend in apical $1 / 3$. Membrane accompanied process $(A m)$ with barbed tip. Membranous process $(M p)$ weakly distinct in light microscope.

Leg measurements: male MRAC 154713 (female MRAC 154713 in parentheses):

\begin{tabular}{c|c|c|c|c|c|c}
\hline & Femur & Patella & Tibia & Metatarsus & Tarsus & Total \\
\hline Palp & $0.39(0.46)$ & $0.23(0.19)$ & $0.43(0.33)$ & - & $0.57(0.36)$ & $1.62(0.34)$ \\
\hline I & $1.00(1.11)$ & $0.81(0.87)$ & $0.57(0.61)$ & $0.29(0.31)$ & $0.29(0.31)$ & $2.96(3.21)$ \\
\hline II & $0.81(0.87)$ & $0.51(0.54)$ & $0.54(0.60)$ & $0.43(0.47)$ & $0.34(0.33)$ & $2.63(2.81)$ \\
\hline III & $0.66(0.74)$ & $0.43(0.50)$ & $0.51(0.50)$ & $0.49(0.49)$ & $0.31(0.33)$ & $2.40(2.56)$ \\
\hline IV & $0.96(1.10)$ & $0.57(0.66)$ & $0.56(0.86)$ & $0.61(0.69)$ & $0.39(0.39)$ & $3.09(3.70)$ \\
\hline
\end{tabular}




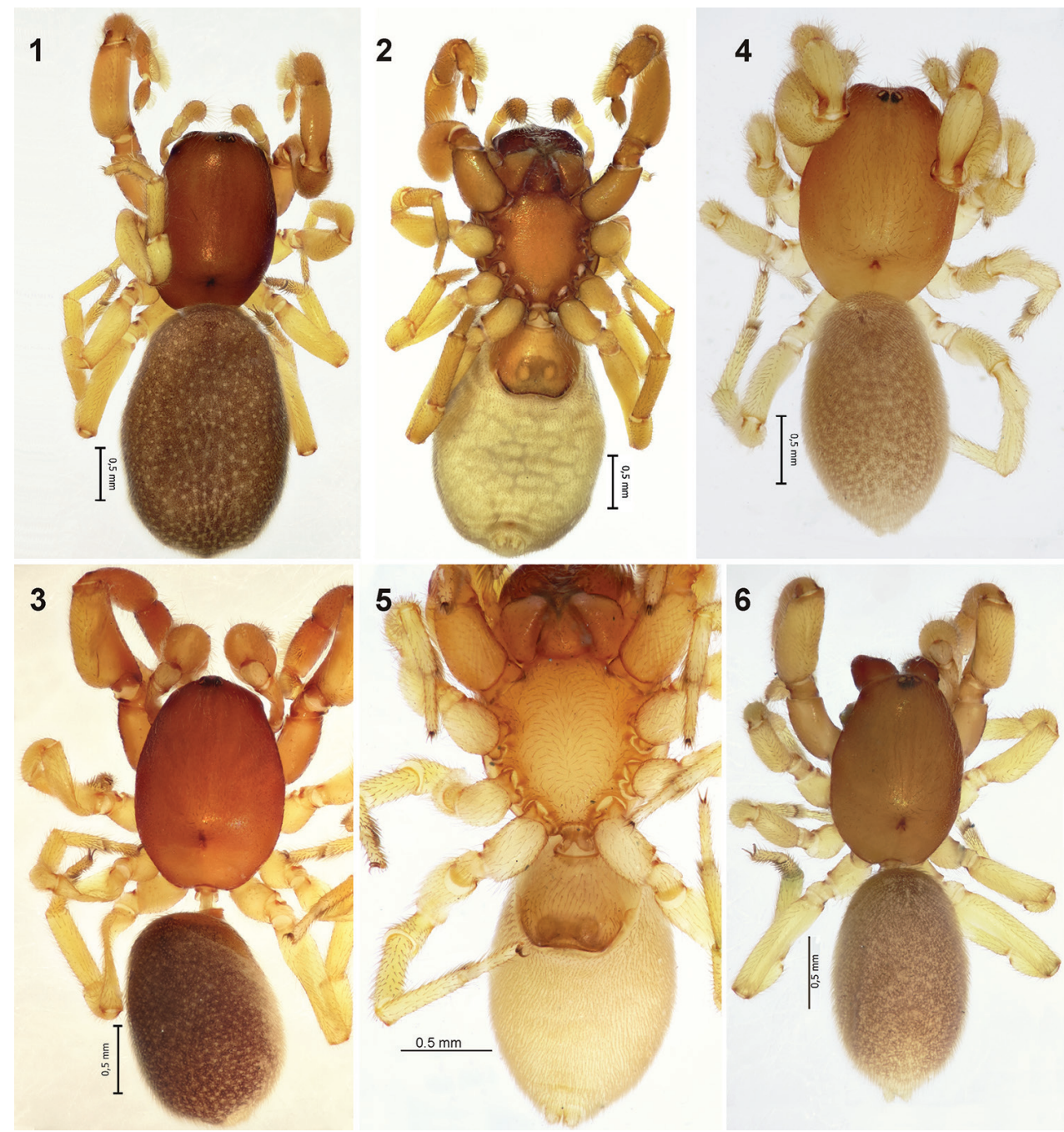

Figures I-6. Habitus of Chedimanops eskovi sp. n. (I-3) and C. rwenzorensis sp. n. (4-6). I, 4 female dorsal 2, 5 female ventral 3, $\mathbf{6}$ male dorsal.

Description female. Female MRAC 154713 (paratype).

Habitus: as in Figs 1, 2, 8. Measurements: TL 4.00, CL 1.76, CW 1.21, CH 0.83, $\mathrm{CyH}$ 0.19, SL 1.00, SW 0.86. Eyes: AME 0.09, AME-AME 0.04. Colouration and most somatic characters as in male. Copulatory organs: as in Figs 49, 67-71. Receptacles oval, clearly visible through integument, spaced from epigastral fold as well as from one another by approximately one diameter. Vulva with large receptacles, touching each other; receptacles with thick wall and relatively small chamber $(C h)$, with 12 visible grape-shaped glands $(G g)$, each gland bearing 2 pores.

Types. Holotype ${ }^{A}$, D.R. CONGO: North Kivu Province, Kikura $\left(0^{\circ} 35^{\prime} \mathrm{N}\right.$, $\left.29^{\circ} 57^{\prime} \mathrm{E}\right), 2000 \mathrm{~m}$, vii-viii.1974, M. Lejeune (MRAC 154713). Paratypes: 1 , 


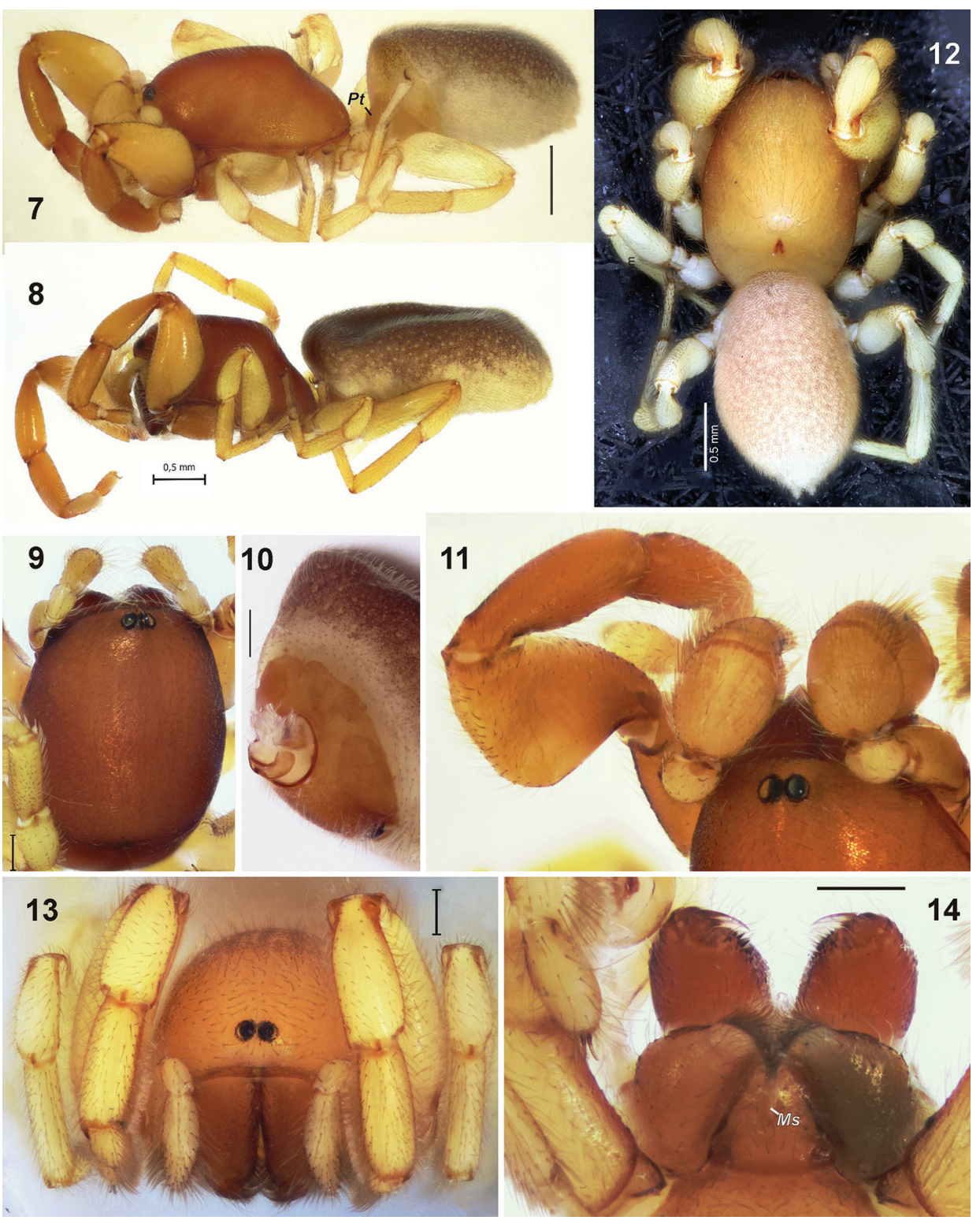

Figures 7-I4. Somatic morphology of Chedimanops eskovi sp. n. (7-II) and C. rwenzorensis sp. n. (I 2-I 4). 7-8 male and female habitus, lateral 9 female prosoma, dorsal $\mathbf{I 0}$ anterior part of female abdomen showing epigastral scutum, antero-lateral I I anterior part of male prosoma, antero-dorsal I $\mathbf{2}$ female habitus, dorsal; 13 male prosoma, anterior $\mathbf{4}$ male mouth parts, ventral. Abbreviation: $M s$ median suture. Scale bars: $0.2 \mathrm{~mm}$ if not otherwise indicated.

2 juv. collected together with the holotype and placed into the same vial; 10,1 , same collecting data (MRAC 154148); $3 \hat{\jmath}, 11$ juv., same collecting data (MRAC 154488). 
Distribution. The species is known only from the type locality (Rwenzori Mts., Democratic Republic of Congo).

Natural history. Probably litter-dwelling spiders (all specimens were collected with pitfall traps).

\section{Chedimanops rwenzorensis sp. $\mathrm{n}$.}

http://zoobank.org/E68C752B-5F58-4452-B6CB-5E269AF71ADF

Figs 4-6, 12-14, 39, 51-52, 61-63, 72-75, 76

Etymology. Named after the distribution area, Rwenzori Mts.

Diagnosis. Differs from C. eskovi sp. n. by its smaller size (carapace less than 1.4 $\mathrm{mm} v$ s. more than 1.6 in C. eskovi sp. n.), paler and less contrasting coloration, with a uniformly pale-coloured ventral surface of the abdomen. In C. rwenzorensis sp. n., the claw-shaped process of the embolus division has one bend, and the receptacles spaced by a distance less than one their radius from the epigastral fold (vs. two bends and approximately one diameter in the other species). Other distinctive characters are listed in the diagnosis of C. eskovi sp. n.

Description male. Male MRAC 223336 (holotype).

Habitus: as in Fig. 6. Measurements: TL 3.0, CL 1.36, CW 0.94, CH 0.51, CyH 0.16, SL 0.86, SW 0.66. Eyes: AME 0.07, AME-AME 0.05. Colour in alcohol: carapace and dorsal scutum light yellowish-orange, chelicerae bright reddish-orange; maxillae and labium light red, sternum slightly paler yellowish-red; palps, leg I and ventral scutum light yellowish-orange, II-IV and ventral abdomen including spinnerets pale pinkish-yellow; abdomen dorsally light chestnut with numerous, dense and uniformly spread small pale yellowish-brown spots, ventrally, including spinnerets, pale grayishyellow. Palp: as in Figs 51-52, 61-63. Femur not swollen; tibial ventral length approximately three times shorter than dorsal length (Figs 51-52). Cymbium short, 1.5 times longer than wide. Claw-shaped process $(C p)$ of the embolic division with two bends. Membranous process $(M p)$ large, well distinct.

Leg measurements: male MRAC 223336 (female MRAC 223336 in parentheses):

\begin{tabular}{c|c|c|c|c|c|c}
\hline & Femur & Patella & Tibia & Metatarsus & Tarsus & Total \\
\hline Palp & $0.36(0.44)$ & $0.17(0.19)$ & $0.34(0.26)$ & - & $0.36(0.30)$ & $1.23(1.19)$ \\
\hline I & $0.87(1.03)$ & $0.67(0.71)$ & $0.53(0.57)$ & $0.29(0.30)$ & $0.33(0.29)$ & $2.69(2.90)$ \\
\hline II & $0.71(0.79)$ & $0.43(0.49)$ & $0.49(0.57)$ & $0.34(0.43)$ & $0.33(0.33)$ & $2.30(2.61)$ \\
\hline III & $0.63(0.71)$ & $0.36(0.41)$ & $0.41(0.46)$ & $0.36(0.44)$ & $0.33(0.34)$ & $2.09(2.36)$ \\
\hline IV & $0.83(0.96)$ & $0.44(0.57)$ & $0.67(0.73)$ & $0.50(0.66)$ & $0.37(0.36)$ & $2.81(3.28)$ \\
\hline
\end{tabular}

Description female. Female MRAC 223336 (paratype).

Habitus: as in Figs 4, 5, 12. Measurements: TL 3.10, CL 1.36, CW 1.11, CH 0.57, $\mathrm{CyH}$ 0.16, SL 0.93, SW 0.79. Eyes: AME 0.07, AME-AME 0.04. Colour in alcohol: as in male. Copulatory organs: as in Figs 5, 39, 72-75. Receptacles clearly visible through 


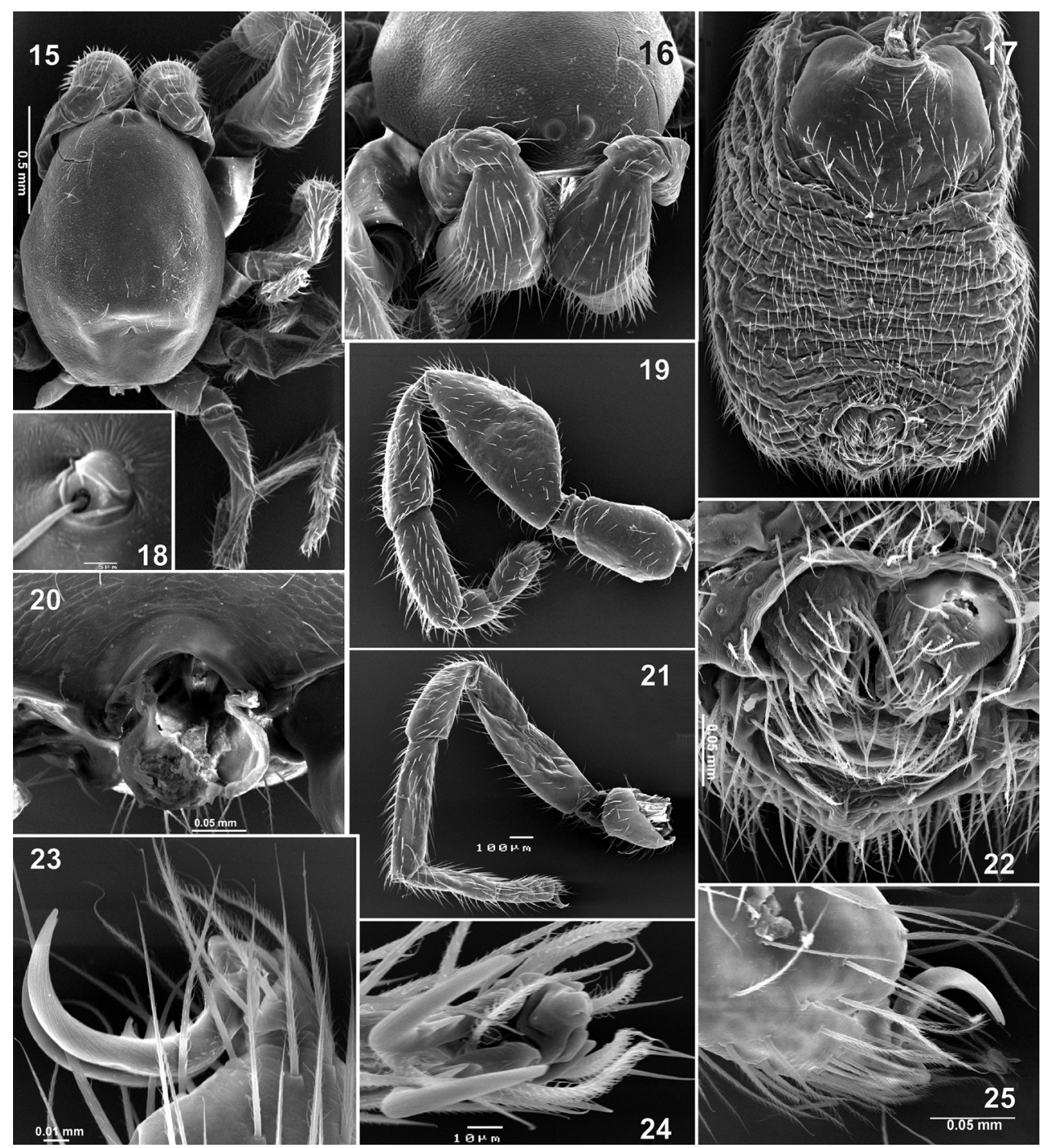

Figures 15-25. SEM micrographs of somatic morphology of subadult male of Chedimanops eskovi sp. n. $\mathbf{I 5}$ prosoma, dorsal $\mathbf{I} \mathbf{6}$ prosoma, frontal $\mathbf{1 7}$ abdomen, ventral $\mathbf{1 8}$ trichobothrium $\mathbf{1 9}$ leg I, retrolateral $\mathbf{2 0}$ posterior part of prosoma, caudal $\mathbf{2 I}$ leg, retrolateral $\mathbf{2 2}$ spinnerets, ventral 23-24 tarsal claws of leg IV, lateral and dorsal $\mathbf{2 5}$ claws of tarsus I, lateral.

integument, round, almost touching posterior edge of epigastral plate; spaced from each other by less than 1 diameter. Vulva with large receptacles, touching each other; receptacles with thick wall and relatively small chamber $(C h)$, with 8 visible grapeshaped glands $(G g)$; fine threads $(F t)$ with fine gland-like structures $(F g)$ on the tips.

Types. Holotype ${ }^{\lambda}$, D.R. CONGO: North Kivu Province, "Migeri" (as labeled) = Kirivata $\left(0^{\circ} 16^{\prime} \mathrm{N}, 29^{\circ} 46^{\prime} \mathrm{E}\right), 1700$ m, 16.iv.1953, P. Vanschuytbroeck \& J. Kekenbosch (MRAC 223336). Paratype $\odot$, collected together with the holotype and placed into the same vial. 


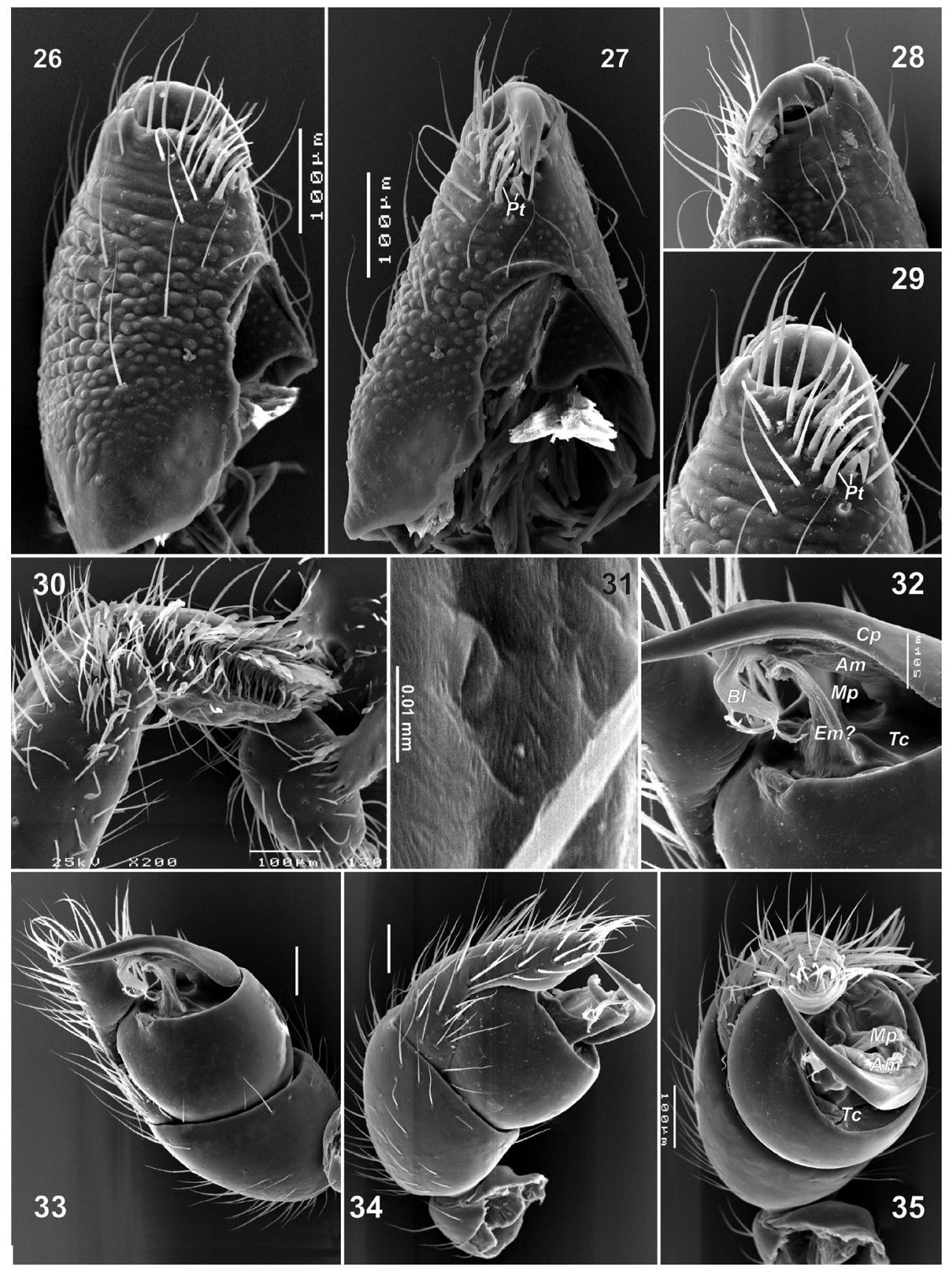

Figures 26-35. SEM micrographs of somatic morphology of subadult male and male palp of Chedimanops eskovi sp. n. 26-27 chelicera, anterior and mesal 28-29 tip of chelicera, posterior and anterior 30 leg I, prolateral $\mathbf{3 0}$ tarsal organ of leg IV $\mathbf{3}$ I terminal part of palp showing embolic division 33-34 palp, ventro-prolateral, prolateral and anterior. Abbreviations: $A m$ accompanying membrane; $B l$ barbed tip of accompanying membrane; $C p$ claw-shaped process; $E m$ ? possible functional embolus; $M p$ membranous process; $T c$ tegular cavity. Scale bar: $0.1 \mathrm{~mm}$ if not otherwise indicated. 

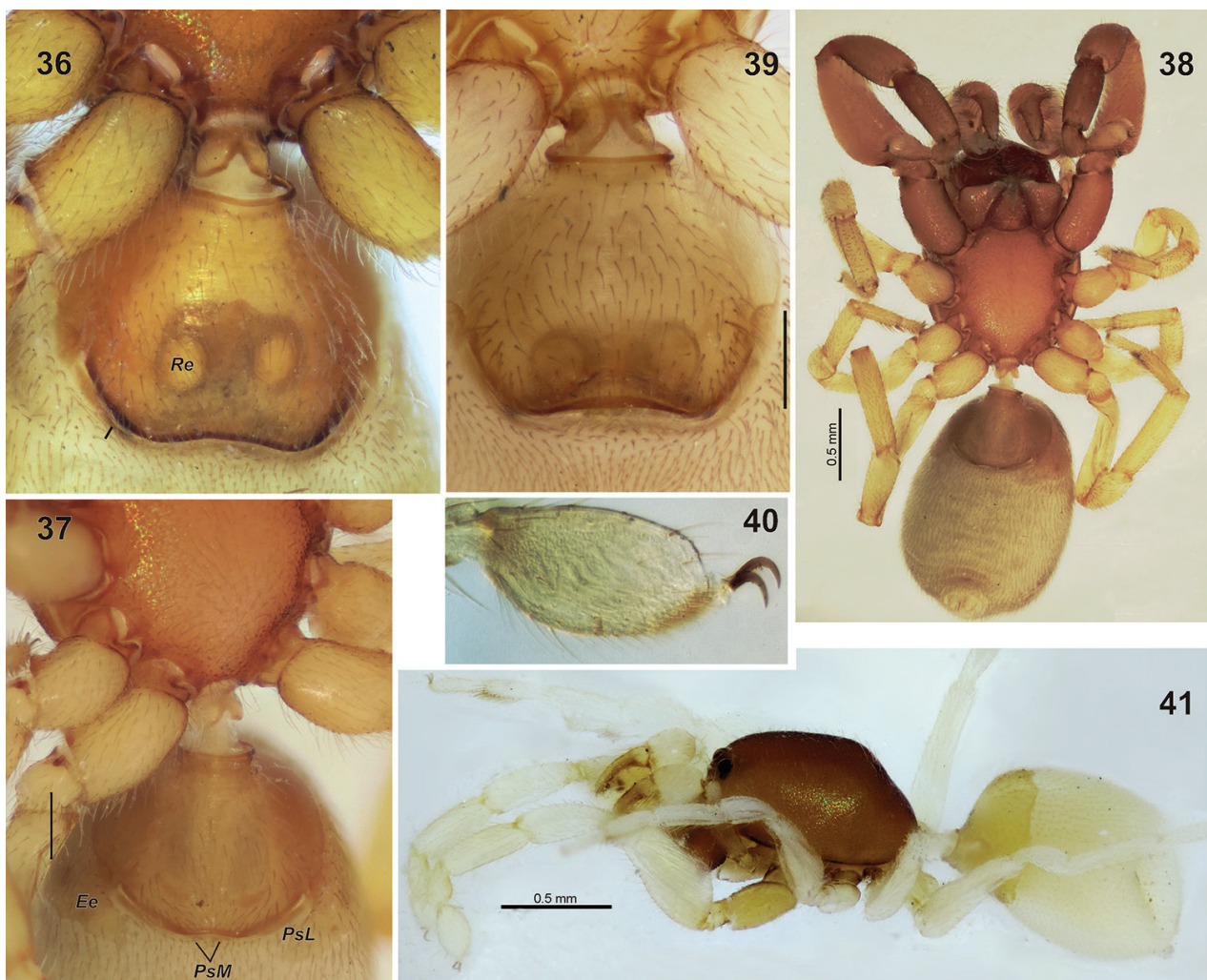

Figures 36-4I. Somatic morphology of Chedimanops eskovi sp. n. (36-38), C. rwenzorensis sp. n. (39) and Hybosidella etinde sp. n. (40-4I). 36, 39 female epigastral scutum, ventral; 37 male epigastral scutum, ventral; $\mathbf{3 8}$ male habitus, ventral; $\mathbf{4 0}$ tarsus I, prolateral; $\mathbf{4 I}$ male habitus, lateral. Abbreviations: Ee extention of epigastric scutum; $P s L$ paired lateral scutum; $P_{s} M$ paired median scutum; Re receptacle. Scale bar: $0.2 \mathrm{~mm}$ if not otherwise indicated.

Distribution. The species is known only from the type locality (Rwenzori Mts., Democratic Republic of Congo).

Natural history. Probably litter-dwelling spiders (both male and female were obtained using a Berlese funnel trap).

\section{Genus Hybosidella gen. n.}

http://zoobank.org/7914854F-9D47-4CFA-B271-147F748A0980

\section{Type species. Hybosidella etinde sp. n.}

Etymology. The generic name is a diminutive of Hybosida, the palpimanid genus, similar in appearance. The gender is feminine.

Diagnosis. The new genus can be easily distinguished from all other known palpimanids, except Chedimanops gen. n., by having only two eyes. Hybosidella gen. n. can be distinguished from Chedimanops gen. $n$. by the much narrower slit-like thoracic 

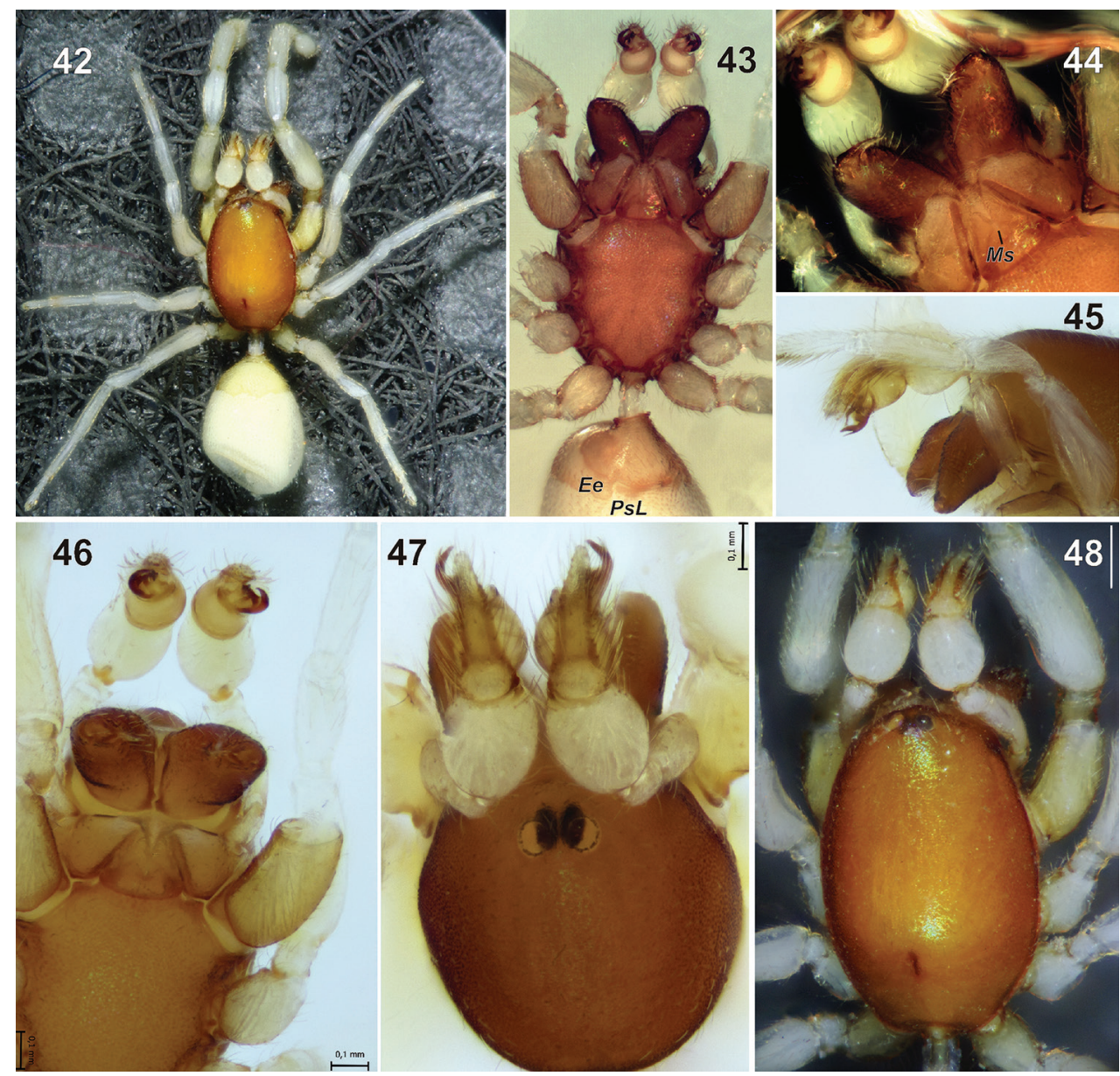

Figures 42-48. Somatic morphology of Hybosidella etinde sp. n. 42 habitus, dorsal $\mathbf{4 3}$ prosoma and anterior part of abdomen, ventral $\mathbf{4 4}$ mouth parts, ventral $\mathbf{4 5}$ prosoma, lateral 46-48 prosoma, ventral, antero-dorsal and dorsal. Abbreviations: Ee extention of epigastric scutum; $M s$ median suture; $P_{s} L$ paired lateral scutum. Scale bar: $0.2 \mathrm{~mm}$ if not otherwise indicated.

fovea, smaller size (carapace less than 1.1 long, vs. more than 1.3 in the latter), lack of lateral extensions $(E e)$ of epigastric scutum (present in Chedimanops gen. n.), wide and short lateral postgastral scuta (thin and long in the latter, cf. Figs 36-39, 43), bifurcated claw-shaped process (undivided in Chedimanops gen. n., $c f$. Figs 49-52, 64-66) and well sclerotized embolus $(E m)$ lacking in related genus ( $c f$. Figs 32, 53).

Description. Body length less than $2.5 \mathrm{~mm}$. Carapace finely granulated, oval in dorsal view and covered with fine setae. Cephalic part distinctly raised behind eye area. Thoracic fovea transverse, very narrow and slit-shaped. Two eyes, only AME present, other eyes lost. Eyes moderately large, spaced by $c a .0 .4$ of their diameter. Clypeus nearly 1.5 times higher than AME diameter. Chelicerae downward-directed, without stridulatory ridges. Sternum with fine reticulation, more coarsely granulated anteriorly. Labium triangular with deep median suture $(M s)$, slightly longer than wide at base. 

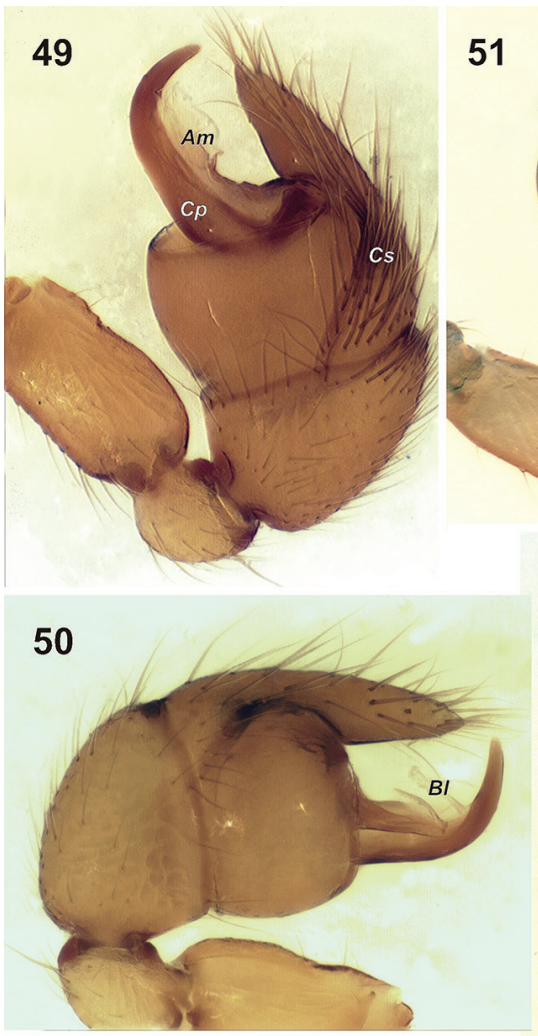
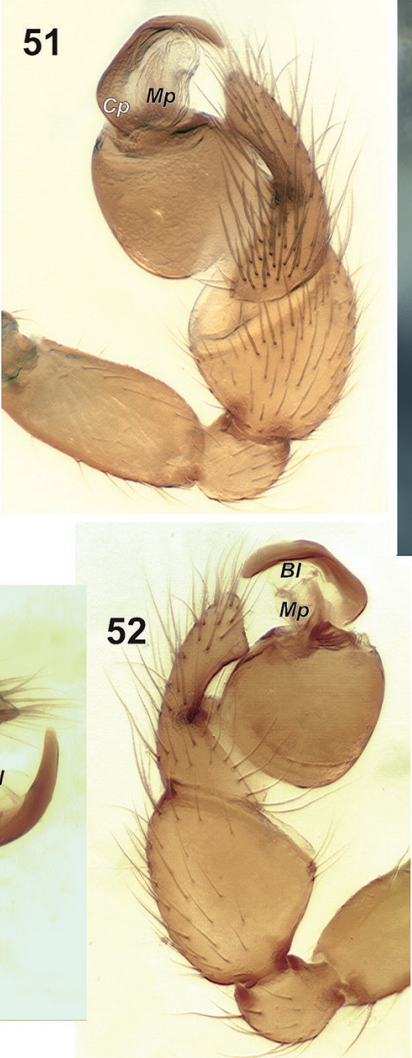
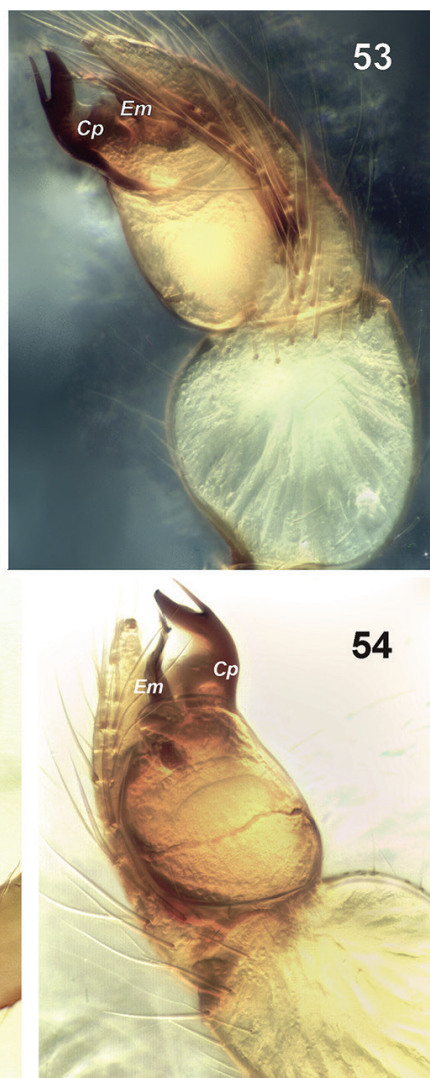

Figures 49-54. Male palp of Chedimanops eskovi sp. n. (49-50), C. rwenzorensis sp. n. (5I-52) and Hybosidella etinde sp. n. (53-54). 49, 5 I, 53 retrolateral 50, 52, 54 prolateral. Abbreviations: Am accompanying membrane; $B l$ barbed tip of accompanying membrane; $C p$ claw-shaped process; $E m$ embolus; $M p$ membranous process.

Legs: formula 1423. Leg cuticle smooth. Femur I moderately swollen; patella shorter than tibia, metatarsus short, tarsus short and dilated (Fig. 40). Tibia I subapically and metatarsus I with dense prolateral scopula. Leg tarsi straight and ascopulate. Claw tufts weakly developed. Leg tarsi with two narrow and weakly dentate claws.

Abdomen: ovoidal, slightly extended anteriorly and obtuse posteriorly. Abdominal scuta conforming a very short pedicel tube; dorsal portion of scutum with well-developed posterior margin. Epigastral scutum without lateral extensions. Postgastral lateral scuta $\left(P_{S} L\right)$ short and wide, median scuta indistinct (if present). AMS small, PMS and PLS not evident.

Male palp: as in Figs 53-54, 64-66. Femur 2.5 times longer than wide; patella almost round, slightly thinner than femur. Tibia strongly swollen, almost as wide as long, approximately 2 times wider than femur, ventral length subequal to dorsal. Cymbium thin and long, ca 2.7 longer than wide. Tegulum longer than wide, more than 1.5 times thinner than patella and lacking processes. Sperm duct not evident. Embolic division embedded into tegular cavity and bears strong, heavily sclerotized claw-shaped process $(C p)$ bifurcated in the terminal $1 / 3$, with both arms sharply pointed, and retro- 


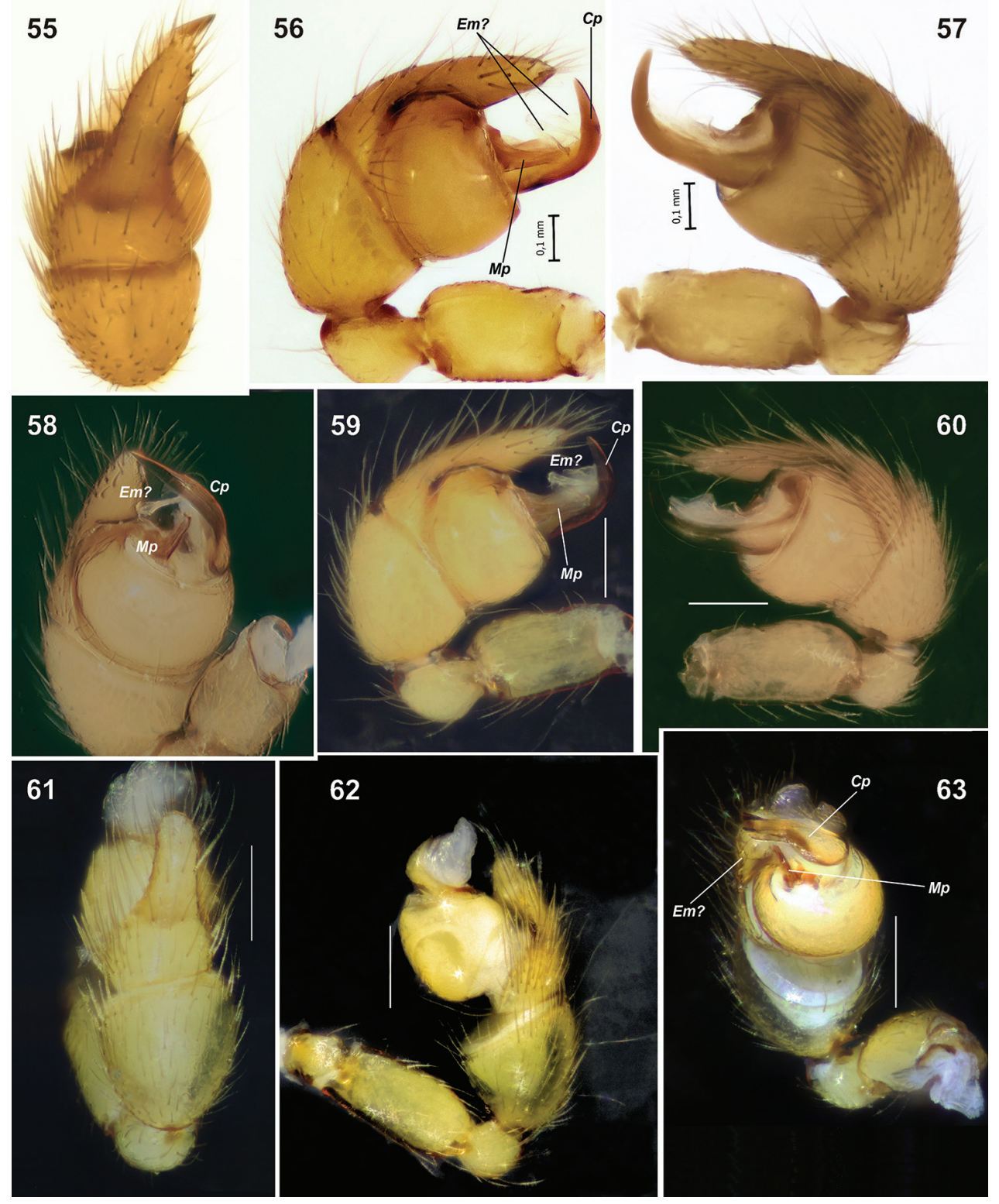

Figures 55-63. Male palp of Chedimanops eskovi sp. n. (55-60) and $C$. rwenzorensis sp. n. (6I-63). 55, 6 I dorsal 56, 59 prolateral 57, 60, 62 retrolateral 63 antero-ventral. Abbreviations: $C p$ claw-shaped process; Em? possible functional embolus; $M p$ membranous process.

lateral arm thicker than prolateral. Embolus $(E m)$ noticeably smaller and shorter than neighbouring outgrowth, wider at base, and bent apically.

Female copulatory organ: unknown.

Species included. The type species only.

Distribution. The genus is currently known only from the southwestern part of Cameroon. 


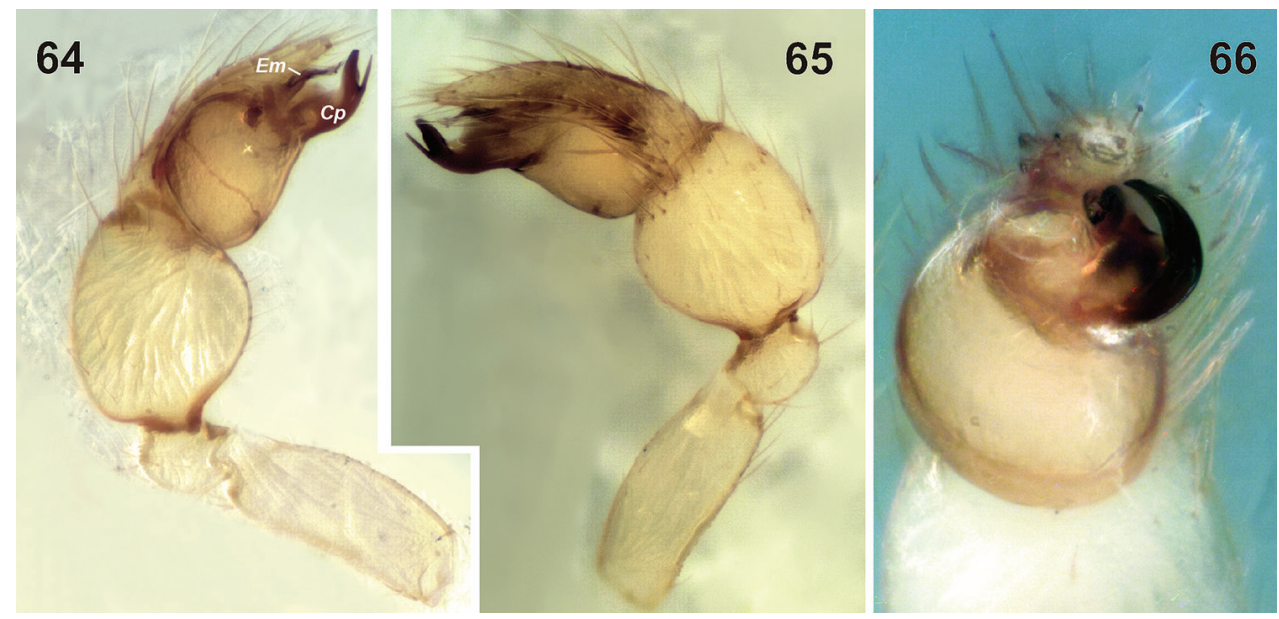

Figures 64-66. Male palp of Hybosidella etinde sp. n. 64 prolateral 65 retrolateral 66 antero-ventral. Abbreviations: $A m$ accompanying membrane; $B l$ barbed tip of accompanying membrane; $C p$ claw-shaped process; Em embolus.

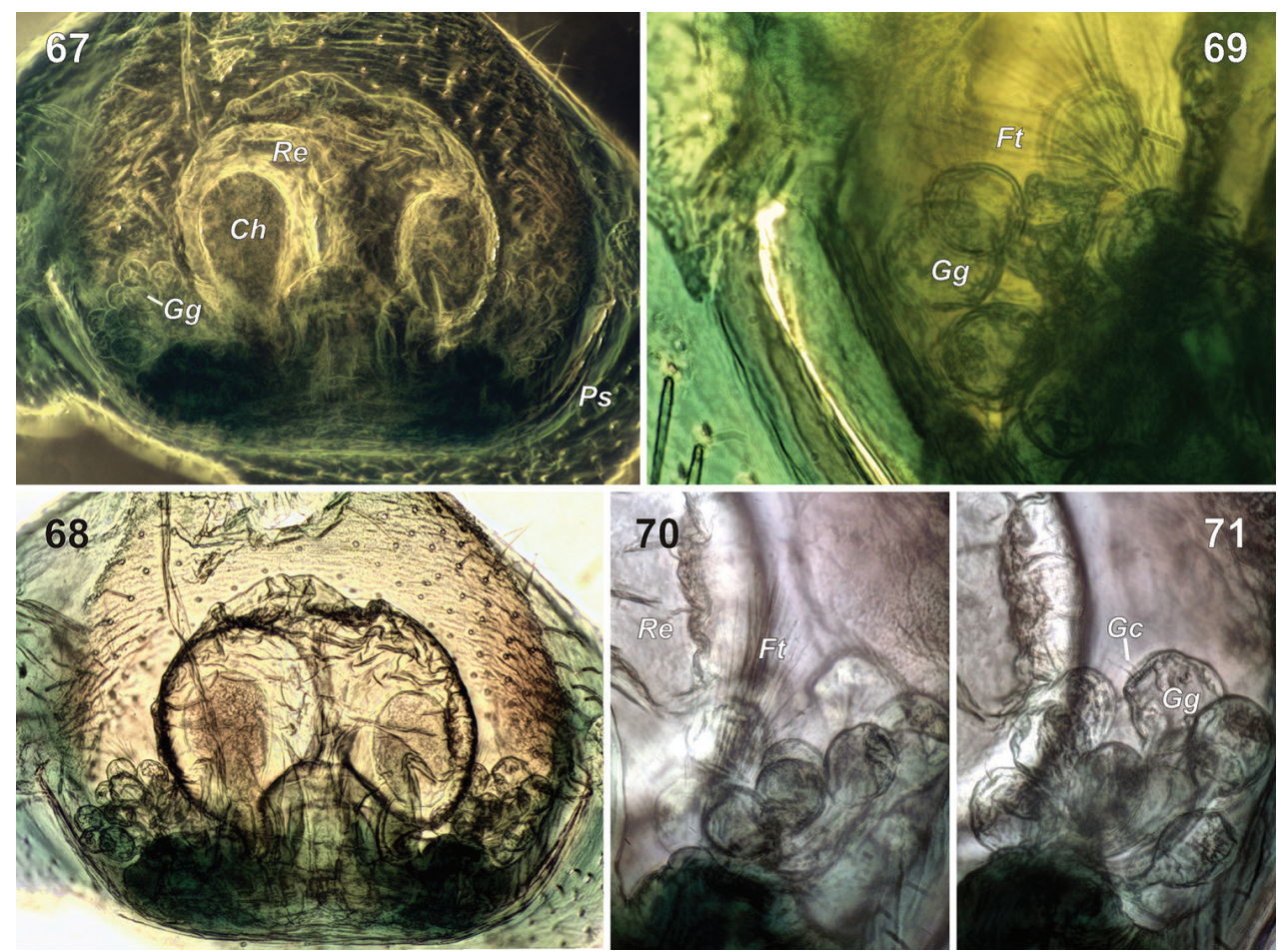

Figures 67-7I. Female copulatory organs of Chedimanops eskovi sp. n. 67-68 vulva, dorsal $\mathbf{6 9}$ details of vulval structures, dorsal 70-7 I details of vulval structures same spot but focused on fine threads $(F t)$ and glandular cilia $(G c)$ respectively. Other abbreviations: $C h$ receptacular chamber; $G g$ grape-shaped glands; $P$ s postgastral scutum; Re receptacle. 

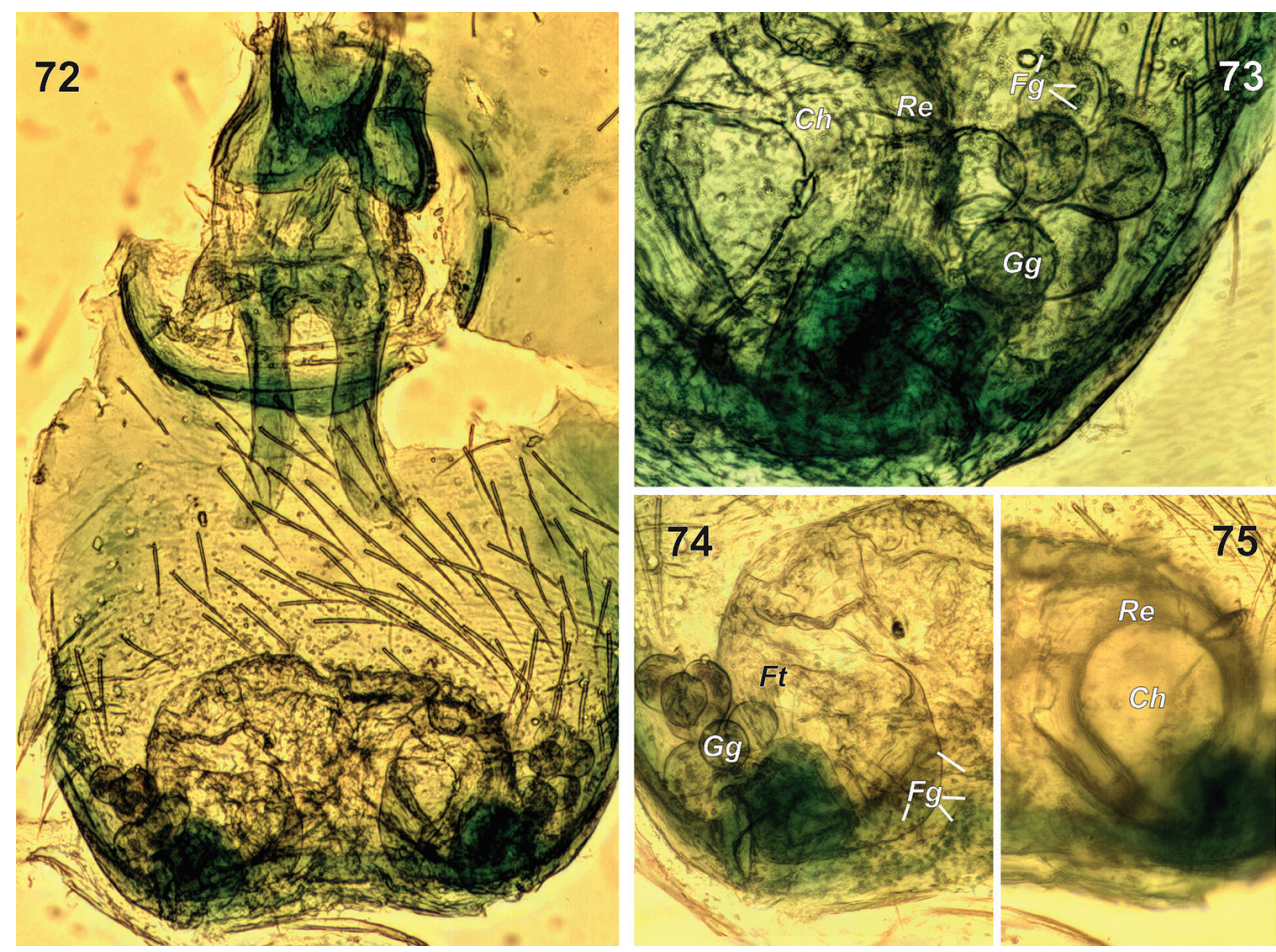

Figures 72-75. Female copulatory organs of Chedimanops rwenzorensis sp. n. 72 epigastral scutum and petiolar sclerites, ventral $\mathbf{7 3}$ details of vulval structures, dorsal $\mathbf{7 4}$ vulva, focused on grape-shaped glands, dorsal 75 right of vulva, focused on receptacle, dorsal. Abbreviations: $C h$ receptacular chamber; $F g$ fine glands; Ft fine threads; $G g$ grape-shaped glands; Re receptacle.

\section{Hybosidella etinde sp. $\mathrm{n}$.}

http://zoobank.org/AF19CA29-CF10-4EFE-B5FF-12EC85BC6E65

Figs 40-48, 53-54, 64-66, 76

Diagnosis. As for the genus.

Etymology. Named after the distribution area: Mt Etinde in the Cameroon Volcano Massive.

Description. Male MRAC 162531(holotype).

Habitus: as in Figs 41, 42. Measurements: TL 2.43, CL 1.07, CW 0.71, CH 0.47; $\mathrm{CyH}$ 0.13, SL 0.67, CW 0.53. Eyes: AME 0.09, AME-AME 0.04. Colour in alcohol: carapace and chelicerae bright yellowish-orange, sternum, labium and basal part of maxillae light yellowish-pink; leg coxae I-IV, cymbium, bulb, dorsal and ventral abdominal scuta pale pinkish-yellow, palps, legs and most part of abdomen including spinnerets uniformly pale milky-white. Palp: as in Figs 53-54, 64-66. Description same as for the genus. 


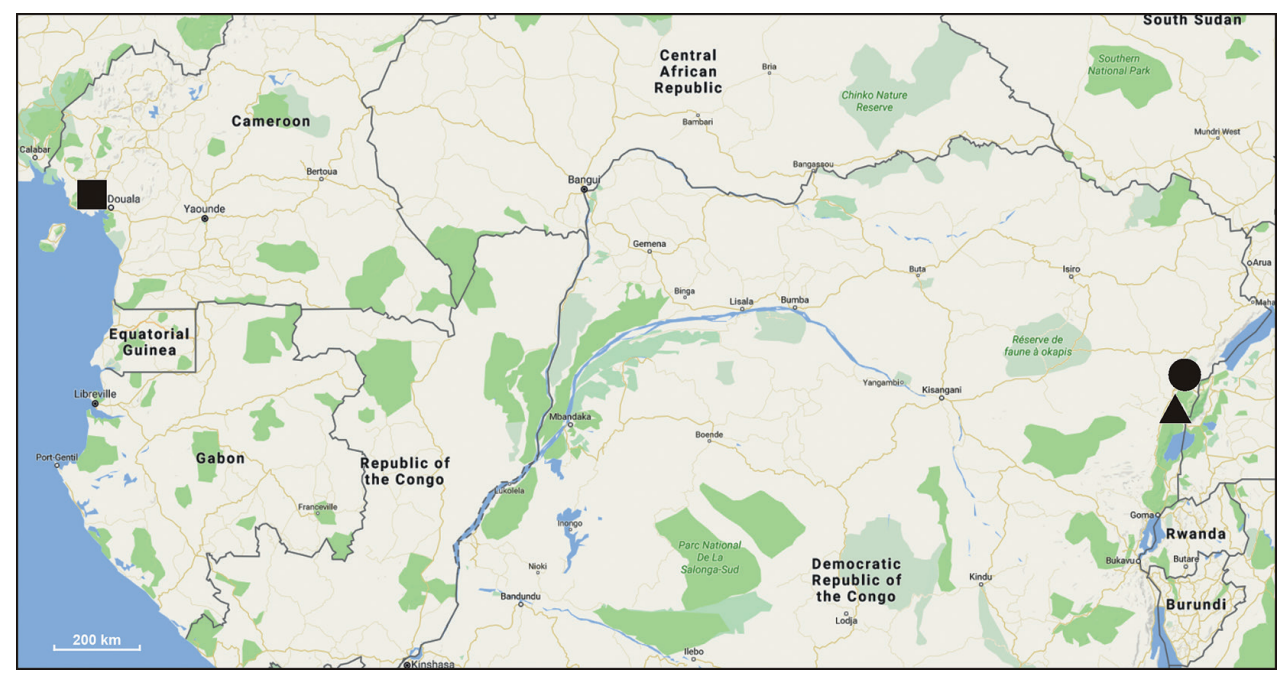

Figure 76. Distribution of Chedimanops gen. n. and Hybosidella gen. n. C. eskovi sp. n. (circle), C. rwenzorensis sp. n. (triangle) and $H$. etinde sp. n. (square).

Leg measurements:

\begin{tabular}{c|c|c|c|c|c|c}
\hline & Femur & Patella & Tibia & Metatarsus & Tarsus & Total \\
\hline Palp & 0.29 & 0.11 & 0.27 & - & 0.33 & 1.00 \\
\hline I & 0.64 & 0.51 & 0.39 & 0.26 & 0.26 & 2.06 \\
\hline II & 0.50 & 0.33 & 0.36 & 0.26 & 0.26 & 1.71 \\
\hline III & 0.51 & 0.26 & 0.33 & 0.29 & 0.24 & 1.63 \\
\hline IV & 0.71 & 0.31 & 0.5 & 0.46 & 0.29 & 2.27 \\
\hline
\end{tabular}

Female. Unknown.

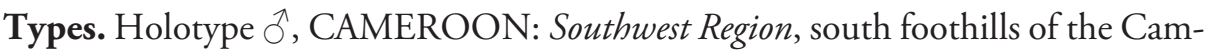
eroon Volcano Massive, Etinde (406'N, 909'E), 500 m, 18.iii.1981, R. Bosmans \& J. Van Stalle (MRAC 162531).

Distribution. The species is known only from the type locality.

Natural history. According to the label data, the holotype male was collected with pitfall traps in lowland rain forest near a stream.

\section{Discussion}

\section{General notes}

Simon (1893) divided all the palpimanids known to him into two tribes, according to the eye pattern. The tribe Chedimeae was established for the spiders with anterior and posterior lateral eyes almost touching each other. Simon assigned the rest of the palpimanids (with widely spaced lateral eyes) into the nominative tribe Palpimaneae. 
Platnick (1975) elevated both the above-mentioned groups to subfamily rank. He also separated these taxa from another subfamily concurrently described in his work, the Otiothopinae, by possessing accessory terminal sclerites in the male bulb (present in the former groups, but absent in the latter). Additionally, the Otiothopinae have been found to be an exclusively Neotropical group (Platnick et al. 1999), while the subfamily Chediminae is a chiefly Paleotropical taxon, with only some representatives distributed also in a few adjoining far southern Palearctic areas (Simon 1873; Hu and Li 1987; Zonstein and Marusik 2013; El-Hennawy 2014; Zonstein et al. in press). The subfamily Palpimaninae is widely distributed in Africa, the Mediterranean Region, Middle East and Central Asia, but is very poorly represented in the Oriental Region (WSC 2016). The puzzling occurrence of Palpimanus argentinus Mello-Leitão, 1927 in South America is still based exclusively on the old collection data, and since description has not been confirmed by field studies. The only representative, collected by F. Silvestri, is kept in the Simon's collection in Paris. Conforming to Mello-Leitão (1927), it originates from Salta (Argentina). However, on the labels (even those based on the received material), E. Simon rarely noted the collection country name, but mostly only locality. Thus, the specimen interpreted as South American could actually have been collected by F. Silvestri from Salto (Italy). In view of the complete absence of later records, this suggestion seems to be more reasonable than assuming that the species was occasionally introduced (see Platnick 1975).

For the above-mentioned reasons (structure of the male palp and the geographical confinement), the following discussion will deal with only two Old World subfamilies, Palpimaninae and Chediminae.

The nominative subfamily Palpimaninae currently comprises 2 genera and 37 very uniformly looking species: the widespread Palpimanus Dufour, 1820 (35) and South African Ikuma Lawrence, 1938 (2). Prior to this study, the more diverse subfamily Chediminae was considered to include 9 genera and 31 species: Boagrius Simon, 1893 (2), Chedima Simon, 1873 (1), Hybosida Simon, 1898 (4), Diaphorocellus Simon, 1893 (4), Levymanus Zonstein \& Marusik, 2013 (1), Sarascelis Simon, 1887 (7), Scelidocteus Simon, 1907 (7), Scelidomachus Pocock, 1899 (1) and Steriphopus Simon, 1887 (4). The distribution of almost two-thirds of these species (23) is confined to tropical Africa (counted from WSC 2016). Most probably, the monotypic Badia Roewer, 1962 was misplaced in the Palpimanidae, and in any case it should be certainly excluded from the chedimine genera because, unlike the Chediminae, B. rugosa Roewer, 1962 was shown to have widely spaced lateral eyes (see Zonstein and Marusik 2013).

\section{A survey of characters}

Since the representatives of Chedimanops gen. n. and Hybosidella gen. n. completely lack the lateral eyes, they cannot be assigned to any of the two Old World subfamilies by using such a simple and traditional criterion as the distance between ALE and PLE. Therefore, any reliable suggestion concerning the taxonomic position of the two 
newly-described genera should be based on the available characters. These potentially diagnostic features are surveyed below.

Body size: The Palpimanidae of the Old World can be divided into two informal groups. The first includes the tiny palpimanids $2-4 \mathrm{~mm}$ long, belonging to the genera Hybosida, Levymanus and Steriphopus (see Platnick 1979; Hu 2001; Zonstein and Marusik 2013). Small (approximately $3 \mathrm{~mm}$ ) south Asian Boagrius pumilus Simon, 1893 also belongs to the latter group. The considerably larger African B. incisus Tullgren, 1910, with body length 7-8 mm ( 10 syntypes in NRS, examined) is in our opinion misplaced in this genus. The latter group includes the rest of the chedimine genera and all representatives of the Palpimaninae. In members of Chedima, Diaphorocellus, Sarascelis, Scelidocteus, and Scelidomachus the body is 4.5-8.5 mm long (Simon 1873, 1907; Pocock 1899; Jézéquel 1964; Benoit 1974; Zonstein et al. 2016). In some smaller members of Scelidocteus it varies from 4 to $5 \mathrm{~mm}$ long (Simon 1907). According to Nentwig et al. (2016), in the Mediterranean species of Palpimanus, occurring in southern Europe, body length ranges from 4.4 to $7.6 \mathrm{~mm}$. African representatives of Palpimanus and adult members of Ikuma are 4.5-13.0 mm long (see Pocock 1898, Simon 1907, 1910; Lawrence 1927, 1937, 1938, 1947, 1952, 1962; Lessert 1936; Benoit 1974).

Thoracic fovea: In most chedimine genera and in all representatives of the Palpimaninae, the fovea is represented by a narrow, short and deep, and bilaterally constricted longitudinal groove (as shown in Marusik and Zonstein 2013: figs 3-5, 7). In Scelidocteus, the fovea is anchor-like and widened posteriorly (Forster and Platnick 1984: fig. 283). A modified variant of this type can be observed in Hybosida and Steriphopus, possessing the angular and opened posteriorly triangular or $\Lambda$-shaped (lambda-shaped) foveal groove (Platnick 1979: fig. 1; Saaristo 2010: fig. 24.1). The posteriorly opening fovea is also characteristic for Boagrius pumilus (see Murphy and Murphy 2000: fam. 45: fig. 1). In Diaphorocellus, the right and left parts of the fovea show a certain tendency for further separation from one another (Zonstein et al. 2016: fig. 6). Finally, in Levymanus the thoracic fovea is represented by two separate sulci located side by side (Zonstein and Marusik 2013: figs. 10, 12; Zonstein et al. in press). It should be noted that all the mentioned modifications are characteristic for genera of the subfamily Chediminae, but not for those of the Palpimaninae (see Cerveira and Jackson 2005: fig. 1).

Abdominal scuta: Within the Palpimaninae, the anterior part of the abdomen overhangs the posterior part of the carapace, making a dorsal portion of the scutum de facto frontal and thus invisible from above in both males and females (see Cerveira and Jackson 2005: figs 1-3; Lecigne 2016: fig. 9G). In contrast, in the Chediminae the abdomen is more evenly expanded by the middle, and the dorsal portion of the scutum in a dorsal view becomes visible, almost always in males and very often in females (Platnick 1979: figs 1, 3; Hu 2001: figs 8-15; Deeleman-Reinhold 2001: fig. 76; Zonstein and Marusik 2013: figs 1-9, 12, 14, 15; Zonstein et al. 2016: figs 1, 3, 5).

Male copulatory organs: In the nominative subfamily, the embolus is represented with a fairly robust and rigid heavy-sclerotised process which seems to be quite com- 
mensurable with the "conductor" (or the tegular appendage, sensu Jocqué and Dippenaar-Schoeman 2006: fig. 75i- j). This is true at least for those representatives of the Palpimaninae in which construction of the palpal organ has been examined and illustrated - in some Mediterranean species of Palpimanus Dufour, 1820 (Platnick 1981: figs 1-9), African P. crudeni Lessert, 1936, P. giltayi Lessert, 1936, P. pseudarmatus Lawrence, 1952, P. tuberculatus Lawrence, 1952, P. stridulator Lawrence, 1962, and $P$. lualabanus Benoit, 1974 (Lessert 1936: figs 15-18; Lawrence 1952: figs 19, 20; 1962 : fig. 1e-f; Benoit 1974: figs 16-17), and Asian P. sogdianus Charitonov, 1946 (Marusik and Guseinov 2003: figs 29-32). Within the Chediminae, the embolus is thinner, weaker and more fragile and it is certainly smaller than the surrounding outgrowths. Most often, this difference may be very sharply expressed, e.g. in Hybosida (Simon and Fage 1922: fig. V2; Platnick 1979: figs 5-7, 10-12), Sarascelis (Jézéquel 1964: figs 7b, 9a-b, 11a), Steriphopus (Hu 2001: figs 8-15), Levymanus (Zonstein and Marusik 2013: figs 41-46), and Diaphorocellus (Zonstein et al. 2016: figs 11-15, 17, 18). The same holds true for Chedima and Scelidomachus (Zonstein and Marusik, in prep.). In some species of Scelidocteus the embolus appears stronger; however, even in this case it conforms to the general trend, being noticeably thinner than the "conductor" (Lessert 1930: fig. 4; Jézéquel 1964: fig. 2a-b; Benoit 1974: figs 8, 9, 12, 13; DippenaarSchoeman 2006: fig. 75i-j).

Female copulatory organs: The ventral surface of the epigastric scutum in females, carrying a pair of the fairly well expressed transversal S-shaped or V-shaped sclerotized marks, is very characteristic for the Palpimaninae (Lawrence 1927: fig. 53; 1938: fig. 3; 1962: fig. 1d; Kritscher 1996: fig. 1; Marusik and Guseinov 2003: figs 33, 35, marked as $c$ ), but is rarely observed within the Chediminae (e.g. in Diaphorocellus - Lawrence 1927: fig. 54; Zonstein et al. 2016: fig. 2). Most chedimine genera lack such marks (see Platnick 1979: figs 8, 14; Saaristo 2010: fig. 3; Zonstein and Marusik 2013: fig. 13). In those species of Palpimanus in which the structure of the endogyne has been studied (the Mediterranean congeners, Asian P. sogdianus, African P. transvalicus), the receptacles are fairly large, extended and weakly sclerotized (as shown in Platnick 1981: figs 10-18; Marusik and Guseinov 2003: fig. 35). In contrast, in representatives of the Chediminae subjected to a special examination, the endogyne is shown to be more compact, with mostly round or oval, and more sclerotized receptacles (Jézéquel 1964: figs 1, 3, 6, 8, 10; Platnick 1979: figs 9, 15; Zonstein and Marusik 2013: fig. 49-50; Zonstein et al. 2016: figs. 20-26).

\section{Relationships}

As has been shown above, Chedimanops gen. $\mathrm{n}$. and Hybosidella gen. $\mathrm{n}$. include very minute spiders, with males having the upper part of the abdominal scutum well-visible in the dorsal projection (Figs 3, 6, 7, 41, 42), and a fragile embolus surrounded by stouter conducting outgrowths (Figs 49-54, 56-60, 62-66). All these features are fairly characteristic for taxa within the Chediminae, while none of them have been found 
in the Palpimaninae (see above). Thus, regardless of the full absence of the lateral eyes, there is nothing to prevent these genera from being placed in the Chediminae.

Despite the fact that, unlike all other palpimanids, Chedimanops gen. n. and $H y$ bosidella gen. n. comprise only two-eyed species, these two genera cannot be considered as closely related. Strictly speaking, there is nothing else in common, other than their similar diminutiveness, similar eye reduction, and the characters shared within the entire subfamily Chediminae (see above). In both species of Chedimanops gen. n., the carapace with a $\Lambda$-shaped and posteriorly opened thoracic fovea is combined with a spotted dorsal abdominal pattern (Figs 1, 3, 4, 6, 12, 15). The similar shape of the thoracic fovea is documented for Hybosida and Steriphopus (cf. Platnick 1979: fig. 1; Saaristo 2010: fig. 24.1), whereas a spotted abdominal pattern is characteristic for Chedima (see the corresponding description by Simon 1873). In contrast, like the majority of the chedimine palpimanids, Hybosidella etinde gen. et sp. $n$. has the carapace with a narrowly-closed thoracic groove and a uniformly pale-coloured abdomen behind the sclerotised shields (Figs 41, 42, 48). Within the Chediminae, the male palpal organ provided with a long and bent claw-shaped outgrowth, like that in Chedimanops gen. n., is characteristic for Chedima (Zonstein and Marusik, in prep.). The structure of the palpal organ in Hybosidella etinde gen. et sp. n. resembles that in Scelidomachus socotranus Pocock, 1899 , with the amendment that the apically dilated conductor is bifurcate in the former, but tridentate in the latter taxon (cf. Figs 53, 54, 64-66 and Pocock 1903: p. 194, text-figure).

\section{Acknowledgements}

We thank Rudy Jocqué (MRAC) for enabling us to examine the African palpimanids deposited in this museum; Ansie Dippenaar-Schoeman and Petro Marais (NCA), Peter Jäger and Julia Altmann (SMF), Janet Beccaloni (NHML), and Torbjörn Kronstedt (NRS) for the opportunity to examine the comparative material, and Naomi Paz (TelAviv University), language editor of the final draft. We also thank Charles Haddad and Ricardo Ott for their valuable comments and recommendations. Special thanks are due to Seppo Koponen (ZMUT) for providing us with museum facilities. This study was supported in part by the Israeli Ministry of Absorption.

\section{References}

Benoit PLG (1974) Notules arachnologiques africaines. III. Revue Zoologique Africaine 88: 427-436.

Deeleman-Reinhold CL (2001) Forest spiders of South East Asia: with a revision of the sac and ground spiders (Araneae: Clubionidae, Corinnidae, Liocranidae, Gnaphosidae, Prodidomidae and Trochanteriidae). Brill, Leiden, 591 pp. 
Cerveira AM, Jackson RR (2005) Specialised predation by Palpimanus sp. (Araneae: Palpimanidae) on jumping spiders (Araneae: Salticidae). Journal of East African Natural History 94(2): 303-317. https://doi.org/10.2982/0012-8317(2005)94[303:SPBPSA]2.0.CO;2

El-Hennawy HK (2014) The first record of Levymanus gershomi in Saudi Arabia (Araneae, Palpimanidae). Serket 14(2): 97-101.

Forster RR, Platnick NI (1984) A review of the archaeid spiders and their relatives, with notes on the limits of the superfamily Palpimanoidea (Arachnida, Araneae). Bulletin of the American Museum of Natural History 178: 1-106.

Hu JL (2001) Spiders in Qinghai-Tibet plateau of China. Henan Science and Technology Publishing House, Zhengzhou, 658 pp.

$\mathrm{Hu}$ JL, Li AH (1987) The spiders collected from the fields and the forests of Xizang Autonomous Region, China. (1). Agricultural Insects, Spiders, Plant Diseases and Weeds of Xizang 1: 315-392.

Jézéquel J-F (1964) Araignées de la savane de Singrobo (Côte d'Ivoire). II. Palpimanidae et Zodariidae. Bulletin du Muséum National d'Histoire Naturelle de Paris 36: 326-338.

Jocqué R, Dippenaar-Schoeman AS (2006) Spider Families of the World. Musée Royal de l'Afrique Central, Tervuren, $336 \mathrm{pp}$.

Kritscher E (1996) Ein Beitrag zur Kenntnis der Spinnen-Fauna der Maltesischen Inseln (Chelicerata: Araneae). Annalen des Naturhistorischen Museums in Wien, Serie B 98: 117-156.

Lawrence RF (1927) Contributions to a knowledge of the fauna of South-West Africa V. Arachnida. Annals of the South African Museum 25 (1): 1-75.

Lawrence RF (1937) A collection of Arachnida from Zululand. Annals of the Natal Museum 8: 211-273.

Lawrence RF (1938) Transvaal Museum Expedition to South-West Africa and Little Namaqualand, May to August 1937. Spiders. Annals of the Transvaal Museum 19: 215-226.

Lawrence RF (1947) A collection of Arachnida made by Dr. I. Trägårdh in Natal and Zululand (1904-1905). Göteborgs Kungliga Vetenskaps och Vitterhets Samhälles Handlingar (B) 5 (9): $1-41$.

Lawrence RF (1952) New spiders from the eastern half of South Africa. Annals of the Natal Museum 12: 183-226.

Lawrence RF (1962) Spiders of the Namib desert. Annals of the Transvaal Museum 24: 197-211. Lecigne S (2016) Contribution à la connaissance de l'aranéofaune (Araneae) de Crète (Grèce) et description de la femelle inconnue de Neaetha absheronica Logunov \& Guseinov, 2002 (Salticidae). Nieuwsbrief van de Belgische Arachnologische Vereniging 30 (3): 95-118.

Lehtinen PT (1981) Spiders of the Oriental-Australian region. III. Tetrablemmidae, with a world revision. Acta Zoologica Fennica 162: 1-151.

Lessert R (1930) Araignées du Congo recueillies au cours de l'expédition par l'American Muséum (1909-1915). Quatrieme et derniere partie. Revue Suisse de Zoologie 37: 613-672. https://doi.org/10.5962/bhl.part.117639

Lessert R (1936) Araignées de l'Afrique orientale portugaise, recueillies par MM. P. Lesne et B.B. Cott. Revue Suisse de Zoologie 43: 207-306. https://doi.org/10.5962/bhl.part.144393 
Marusik YM, Guseinov EF (2003) Spiders (Arachnida: Aranei) of Azerbaijan. 1. New family and genus records. Arthropoda Selecta 12: 29-46.

Mello-Leitão CF de (1927) Notes sur quelques araignées brésiliennes de la collection E. Simon.

1. Les palpimanides de l'Amérique du Sud. Bulletin du Muséum National d'Histoire Naturelle de Paris 1927: 86-92.

Murphy F, Murphy J (2000) Spiders of South East Asia. United Selangor Press, Kuala Lumpur, 625 pp.

Nentwig W, Blick T, Gloor D, Hänggi A, Kropf C (2016) Spiders of Europe. http://www. araneae.unibe.ch [version 11.2016, accessed on 17.11.2016]

Platnick NI (1975) A revision of the palpimanid spiders of the new subfamily Otiothopinae (Araneae, Palpimanidae). American Museum Novitates 2562: 1-32.

Platnick NI (1979) Contributions à l'étude de la faune terrestre des îles granitiques de l'archipel des Séchelles (Mission P.L.G. Benoit - J.J. Van Mol 1972). Araneae: Palpimanidae. Revue Zoologique Africaine 93: 461-466.

Platnick NI (1981) A review of the spider subfamily Palpimaninae (Araneae, Palpimanidae), I. Bulletin of the British Arachnological Society 5: 169-173.

Platnick NI (1993) A new genus of the spider family Caponiidae (Araneae, Haplogynae) from California. American Museum Novitates 3063: 1-8.

Platnick NI (2000) On Coxapopha, a new genus of the spider family Oonopidae from Panama (Araneae Haplogynae). Memorie della Società Entomologica Italiana, Genova 78: 403-410.

Platnick NI, Forster RR (1982) On the Micromygalinae, a new subfamily of mygalomorph spiders (Araneae, Microstigmatidae). American Museum Novitates 2734: 1-13.

Platnick NI, Grismado CJ, Ramírez MJ (1999) On the genera of the spider subfamily Otiothopinae (Araneae, Palpimanidae). American Museum Novitates 3257:1-25.

Pocock RI (1898) The Arachnida from the province of Natal, South Africa, contained in the collection of the British Museum. Annals and Magazine of Natural History 7(2): 197-226. https://doi.org/10.1080/00222939808678036

Pocock RI (1899) The expedition to Socotra. VII. Descriptions of one new genus and four new species of spiders. Bulletin of the Liverpool Museums 2(2): 40-42.

Pocock RI (1903) Arachnida. In: Forbes HO (Ed.) The Natural History of Sokotra and Abdel-Kuri. Special Bulletin of the Liverpool Museum, 175-208.

Saaristo MI (2010) Araneae. In: Gerlach J, Marusik Y (Eds) Arachnida and Myriapoda of the Seychelles islands. Siri Scientific Press, Manchester, UK, 8-306.

Simon E (1873) Aranéides nouveaux ou peu connus du midi de l'Europe. (2me mémoire). Mémoires de la Société Royale des Sciences de Liège (2)5: 187-351.

Simon E (1893) Histoire naturelle des araignées. Paris, 1, 257-488.

Simon E (1907) Arachnides recueillis par L. Fea sur la côte occidentale d'Afrique. 1re partie. Annali del Museo Civico di Storia Naturale di Genova (3) 3: 218-323.

Simon E (1910) Arachnoidea. Araneae (ii). In: Schultze L (Ed.) Zoologische und anthropologische Ergebnisse einer Forschungsreise im Westlichen und zentralen Südafrika. Denkschriften der Medizinisch-Naturwissenschaftlichen Gesellschaft zu Jena 16: 175-218.

Simon E, Fage L (1922) Araneae des grottes de l'Afrique orientale. In: Biospeologica, XLIV. Archives de Zoologie Expérimentale et Générale 60: 523-555. 
World Spider Catalog (2016) World Spider Catalog. Natural History Museum Bern. http:// wsc.nmbe.ch, version 17.5 [accessed on 20.07.2016]

Zonstein S, Marusik YM (2013) On Levymanus, a remarkable new spider genus from Israel, with notes on the Chediminae (Araneae, Palpimanidae). ZooKeys 326: 27-45. https://doi. org/10.3897/zookeys.326.5344

Zonstein SL, Marusik YM, Omelko MM (2016) Redescription of the type species of Diaphorocellus Simon, 1893 (Araneae, Palpimanidae, Chediminae). African Invertebrates 57(2): 93-103. https://doi.org/10.3897/AfrInvertebr.57.9988

Zonstein SL, Marusik YM, Kovblyuk MM (2016) New data on the spider genus Levymanus (Araneae: Palpimanidae). Oriental Insects, 1-6. https://doi.org/10.1080/00305316.2016. 1275989 